\title{
Effect of Organic (Jatropha Cake) and NPK Fertilizers on Improving Biochemical Components and Antioxidant Properties of Five Cowpea (Vigna unguiculata L. Walp.) Genotypes
}

\author{
Pierre Alexandre Eric Djifaby Sombié ${ }^{1}$, Hemayoro Sama ${ }^{2}$, Hamadou Sidibé ${ }^{1} \&$ Martin Kiendrébéogo ${ }^{2}$ \\ ${ }^{1}$ Centre National de la Recherche Scientifique et Technologique, Institut d'Environnement et de Recherches \\ Agricoles, Ouagadougou, Burkina Faso \\ ${ }^{2}$ Laboratoire de Biochimie et de Chimie Appliquées, Université Ouaga I Pr JKZ, Ouagadougou, Burkina Faso \\ Correspondence: Pierre Alexandre Eric Djifaby Sombié, Centre National de la Recherche Scientifique et \\ Technologique, Institut d'Environnement et de Recherches Agricoles, 01 BP 476 Ouagadougou 01, \\ Ouagadougou, Burkina Faso. Tel: 226-7135-5445. E-mail: ericsombie@yahoo.fr
}

Received: April 15, $2019 \quad$ Accepted: May 29, $2019 \quad$ Online Published: July 15, 2019
doi:10.5539/jas.v11n10p48
URL: https://doi.org/10.5539/jas.v11n10p48

\begin{abstract}
Organic and inorganic fertilizers improve the nutritional quality of crop. An experiment in pots of four treatments was conducted in a randomized complete block design in order to evaluate the effect of the application of organic and NPK fertilizers on the biochemical components and antioxidant activities of five cowpea genotypes. Results showed that organic fertilizer and the mixture of organic and NPK fertilizer have significantly $(\mathrm{p}<0.05)$ increased the growth parameters and leaves quality traits of cowpea. The response of cowpea under the different treatment is also function of genotype type. The PCA and the dendrogram performed basis on the different fertilizers effect on growth parameters and leaves quality trait divided the treatments into three main classes. Class I comprising NPK + Jatropha treatment strongly contributed to lycopene, $\beta$-carotene and total chlorophyll contents, height and number of branches. Class II comprising NPK treatment solely and Jatropha treatment solely are highly linked to the variables FRAP, DPPH and protein content. Class III comprising control treatment strongly contributed to salicylic, soluble sugar, phenolics and flavonoids contents, and trypsin inhibition activity. The Jatropha cake could be used solely or in mixture with NPK to improve growth and the quality traits of cowpea leaves.
\end{abstract}

Keyswords: antioxidant activities, biochemical components, cowpea, genotypes, growth parameters, mineral fertilizer, organic fertilizer

\section{Introduction}

Vigna unguiculata (L.) Walp. (Cowpea) is one of the most important food legume crops in Burkina Faso. Cowpea is widely cultivated in Burkina Faso for its high nutritive value and health enhancing attributes (Sombié et al., 2018). Soil infertility is the most important constraint limiting crop yield among resource-poor farmers in developing countries (Ju et al., 2018). Fertilizers play an important role in increasing crop production (Patil, 2010). The application of chemical fertilizers has increased crop production but it depletes soil organic matter content, adversely affect biological and physical properties of soil (Patil, 2010; Verma et al., 2017). Chemical fertilizers have contributed significantly toward the pollution of water, air and soil. The organic fertilizers are used to reduce the adverse effects of synthetic fertilizers on human health and environment. Organic products from natural sources can be sustain agriculture development (Mondal, Datta, \& Mondal, 2015). Animal fertilizer compost, plant waste and industrial waste are the main sources of organic fertilizer (Maria, Rodica, \& Gabriella, 2017). In Burkina Faso, the poor farmers used mostly organic waste materials to increase crop production. Jatropha curcas L. is one of growing interest in bioenergy resource (Sama et al., 2018). Its leaves, stems, fruit hull and seed oilcake are used as potential fertilizer (Primandari et al., 2018). In Burkina Faso, Belwet industry has developed an organic fertilizer based on Jatropha seeds after oil extraction by cold pressing. The aim of this research was to study the effect of fertilizers (Organic and Chemical) on the growth, biochemical components and antioxidant activities of five Cowpea (Vigna unguiculata (L.) Walp.) genotypes. 


\section{Materials and Methods}

\subsection{Plant Materials and Cultivation}

The plant material is constituted of the seeds of five (5) genotypes of Vigna unguiculata. The used genotypes are: Gorom local, Komcallé, IT81D-994, KVx 414-22-2 and CR06-07. These five genotypes were obtained from the oil protein crops breeding program of Saria, Department of Crop Production, Institute of Environment and Agricultural Research (INERA), Burkina Faso. The origin and pedigree of each genotype used are shown in Table 1. The experiment was done in Saria station, INERA (Burkina Faso). Normal agronomic practices were performed from sowing till leaves harvest, using randomized complete block design with three replicates. The seeds were sown in the pots containing a mixture of sand and potting soil in the proportions $2 / 1$. This mixture was previously sterilized at $120^{\circ} \mathrm{C}$ for four (04) hours.

Table 1. Origin and pedigree of cowpea genotypes used

\begin{tabular}{lll}
\hline Genotypes & Origin & Pedigree \\
\hline Komcallé & Burkina Faso & KVx396-4-4 × Sakoula x IT85D-3577 \\
KVx 414-22-2 & Burkina Faso & $($ Ouahigouya local $\times$ KVx396-16-10-2 $\times($ Pobé local $\times$ Vita3 $)$ \\
CR06-07 & Ghana & Landrace \\
IT81D-994 & IITA, Nigeria & [(TVU1190 $\times$ TVU76 $) \times$ TVU2027) $\times$ TVU625] \\
Gorom local & Burkina Faso & Landrace \\
\hline
\end{tabular}

\subsection{Treatment and Design of Experimental Field}

The treatments used were as follows:

T0: Control group. The different cowpea genotypes were not received organic and NPK fertilizers.

T1: NPK group. The plants received $3.2 \mathrm{~g}$ of NPK per pot corresponding to the dose of $100 \mathrm{~kg} / \mathrm{ha}$.

T2: Jatropha group. The different cowpea genotypes received $80 \mathrm{~g}$ of Jatropha cake per pot corresponding to the dose of $2500 \mathrm{~kg} / \mathrm{ha}$.

T3: NPK + Jatropha group. The different cowpea genotypes received $1.6 \mathrm{~g}$ of NPK $+40 \mathrm{~g}$ of Jatropha cake per pot corresponding to the dose of ( $50 \mathrm{~kg} \mathrm{NPK}+1250 \mathrm{~kg}$ Jatropha) $/ \mathrm{ha}$.

Jatropha cake was bought from Belwet industry, Ouagadougou, Burkina Faso. Pots were maintained in the open environment and well-watered every day. The different treatments were replicated thrice and arranged in a randomized block design. The leaves were collected the $20^{\text {th }}$ day of sowing for each genotype to determine the biochemical components and antioxidant activities of each treatment type.

\subsection{Determination of Plant Growth Parameters}

Agronomic characteristics included plant height and number of branches per plant.

\subsection{Determination of Photosynthetic Pigments}

Photosynthetic pigments (Total Chlorophyll) content was determined in fresh leaves samples according to the method described by Wintermans and DeMots (1965). $300 \mathrm{mg}$ of fresh crushed leaves were homogenized in 3 $\mathrm{ml}$ of $95 \%$ ethanol. The mixture was kept for 10 minutes in ice. After centrifugation for 1 minute at $4500 \mathrm{rpm}$, the absorbance of the supernatant was measured at $665 \mathrm{~nm}$ and $649 \mathrm{~nm}$ for total chlorophyll using the below formula. The results are expressed as $\mu \mathrm{g} / 100 \mathrm{mg}$ of fresh leaves extracts $(\mu \mathrm{g} / 100 \mathrm{mg})$.

$$
\text { Total Chlorophyll }(\mu \mathrm{g} / \mathrm{mL})=6.1 \mathrm{OD} \mathrm{nm}+20.04 \mathrm{OD} \mathrm{nm}
$$

\section{$2.5 \beta$-Carotene and Lycopene Contents Determination}

$\beta$-Carotene and lycopene contents were determined according to the method described by Nagata and Yamashita (1992). $100 \mathrm{mg}$ of crushed fresh leaves were vigorously shaken with $10 \mathrm{~mL}$ of ethanol $80 \%$ for $1 \mathrm{~min}$ and centrifuged at $4500 \mathrm{rpm}$ for 10 minutes. The absorbance of the supernatant was measured at 453, 505 and 663 $\mathrm{nm}$. $\beta$-carotene and lycopene contents were calculated according to the following equations:

$$
\begin{gathered}
\text { Lycopene }(\mathrm{mg} / 100 \mathrm{ml})=-0.0458 \mathrm{~A} 663+0.372 \mathrm{~A} 505-0.0806 \mathrm{~A} 453 \\
\beta \text {-carotene }(\mathrm{mg} / 100 \mathrm{ml})=0.216 \mathrm{~A} 663-0.304 \mathrm{~A} 505+0.452 \mathrm{~A} 453
\end{gathered}
$$


The mean values \pm standard deviations of triplicate assays were expressed as $\mu \mathrm{g}$ of $\beta$-Carotene/g and $\mu \mathrm{g}$ of lycopene/g of fresh leaves.

\subsection{Salicylic Acid Content}

$50 \mathrm{mg}$ of fresh leaves were homogenized in $5 \mathrm{ml}$ of distilled water and centrifuged at $4500 \mathrm{rpm}$ for 10 minutes. The salicylic acid content was determined in the supernatant according to the method described by Yang et al. (2018) and expressed as $\mathrm{mg} / \mathrm{g}$ of fresh leaves ( $\mathrm{mg} / \mathrm{g}$ of fresh leaves).

\subsection{Soluble Sugars Content}

$500 \mathrm{mg}$ of leaves were homogenized in $5 \mathrm{ml}$ of $80 \%$ hot ethanol. The homogenate was centrifuged at $4500 \mathrm{rpm}$ for $10 \mathrm{~min}$ after cooling. The supernatant was used to estimate the soluble sugar content of fresh leaves at 490 $\mathrm{nm}$ using the phenol-sulfuric acid method as described by Dubois et al. (1956). The total sugar content was expressed as $\mathrm{mg}$ glucose equivalent/gram of fresh leaves (mg GE/g of fresh leaves).

\subsection{Protein Content and Trypsin Inhibition Potential}

\subsubsection{Extraction of Total Protein}

$500 \mathrm{mg}$ of fresh leaves of each genotype were homogenized in $5 \mathrm{ml}$ protein extraction buffer $(92 \mathrm{mM}$ Tris base $\mathrm{pH} 8.1,23 \mathrm{mM} \mathrm{CaCl}_{2}$ ) and then centrifuged at $4500 \mathrm{rpm}$ for $15 \mathrm{~min}$. The supernatant constituted of total protein extract for each genotype leaves was collected for protein content and trypsin inhibition activity determination.

\subsubsection{Protein Content}

The protein concentration was determined by Bradford (1982) with bovine serum albumin (BSA) as standard.

\subsubsection{Trypsin Inhibition Potential}

Trypsin inhibition assay was determinate according to the method described by Klomklao et al. (2009). $100 \mu$ of trypsin (from bovine pancreas, Sigma) at $0.0125 \mathrm{mg} \mathrm{ml}^{-1}$ were added to $100 \mu 1$ of total protein extract, incubated for $5 \mathrm{~min}$ and after $50 \mu \mathrm{l}$ of $N$ - $\alpha$-Benzoyl-DL-Arginine $p$-Nitroanilide (BAPNA) at $0.8 \mathrm{mg} \mathrm{ml}^{-1}$ were added. The liberated $p$-nitroanilide was followed for $25 \mathrm{~min}$ at $410 \mathrm{~nm}$ using a 96 well spectrometer.

Trypsin inhibition activity of each cowpea leaves was estimated as percentage of inhibition according to the formula:

$$
\text { Percent inhibition }(\%)=\frac{\text { Vmax control }- \text { Vmax sample }}{\text { Vmax control }} \times 100
$$

\subsection{Phenolic Content and Antioxidant Activities}

$500 \mathrm{mg}$ of crushed fresh leaves of each cowpea genotype were extracted with $10 \mathrm{ml}$ of acetone: water (80:20 $\mathrm{v} / \mathrm{v}$ ). The mixture was shaken for $24 \mathrm{~h}$ and centrifuged at $4500 \mathrm{rpm}$ for 15 minutes. The supernatant was used for the quantification of total phenolics and total flavonoids contents and for antioxidant activities.

\subsubsection{Total Phenolics and Total Flavonoids Contents}

The total phenolics and total flavonoids contents of fresh leaves extracts were determined respectively at $760 \mathrm{~nm}$ and $415 \mathrm{~nm}$ using the methods described by Sombié et al. (2018). The total phenolics were expressed as mg of gallic acid equivalent per gram of fresh leaves weight (mg GAE/g of fresh leaves) and total flavonoids expressed as $\mathrm{mg}$ of quercetin equivalents $(\mathrm{QE})$ per gram of fresh leaves weight (mg QE/g of fresh leaves).

\subsubsection{Antioxidant Activities}

\section{(1) Ferric Reducing Antioxidant Power (FRAP) Assay}

The ability of the cowpea leaves extracts to reduce iron (III) to iron (II) was measured at $700 \mathrm{~nm}$ using the method described by Sombié et al. (2011). Iron (III) reducing activity was expressed in $\mu \mathrm{g}$ Quercetin Equivalents per $100 \mathrm{mg}$ of fresh leaves ( $\mu \mathrm{g} \mathrm{QE} / 100 \mathrm{mg}$ of fresh leaves).

\section{(2) DPPH Radical Scavenging Activity}

The ability of cowpea leaves extracts to scavenge the DPPH (2,2-diphenyl-1-picrylhydrazyl) radical was evaluated at $517 \mathrm{~nm}$ as described by Sombié et al. (2011). The means of three values were expressed as $\mu \mathrm{g}$ of Ascorbic Acid Equivalent per $100 \mathrm{mg}$ of leaves ( $\mu \mathrm{g} \mathrm{AAE} / 100 \mathrm{mg}$ leaves fresh weight).

\subsection{Statistical Analysis}

The results are presented as mean \pm SD for triplicate analysis. Two-way analysis of ANOVA variation followed by Tukey's Significant Difference test were used to compare the results and $\mathrm{P}<0.05$ was considered significant. The Pearson correlation test was used to study the different correlations between the growth, biochemical and 
antioxidant parameters. The statistical analysis was performed using XLSTAT version 7.5.2 (Addinsoft, FRANCE) and the graphs were drawn using Graph Pad Prism software version 6.0.

\section{Results}

\subsection{Interaction Effect Between Genotype and Treatment}

The main effect of the fertilizer treatment and its interaction effect with genotype on the cowpea growth parameters, biochemical components and antioxidant traits were significant $(\mathrm{P}<0.0001)$. The plant growth parameters, plant height and number of ramifications are shown in Figure 1.

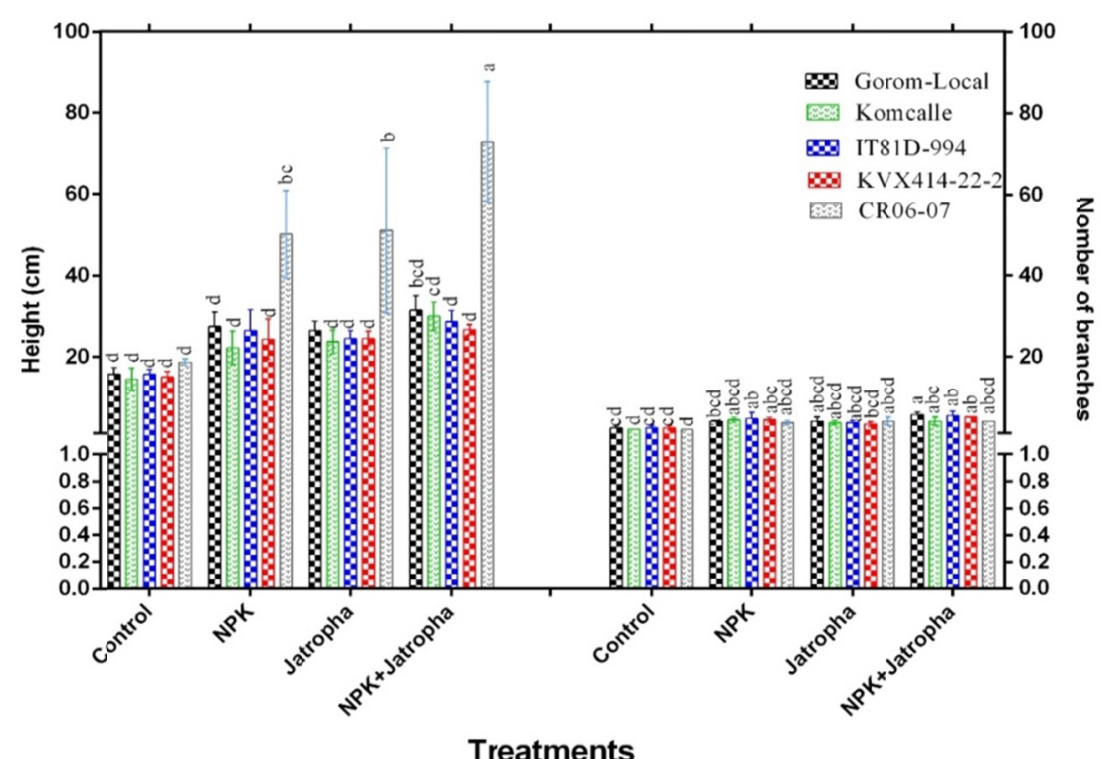

Figure 1. The interaction effect between the genotype and treatment on Height and number of branches of cowpea genotypes

Note. Means followed by the same letter do not differ statistically between the different treatments $(\mathrm{p}<0.05)$.

The CR06-07 genotype treated with NPK + Jatropha possessed the high height of $73 \mathrm{~cm}$, followed by the same genotype treated with Jatropha $(51.167 \mathrm{~cm})$ and NPK $(50.167 \mathrm{~cm})$. The Gorom local genotype treated with the association of NPK + Jatropha possessed the high number of branches (5.667) followed by IT81D-994 and KVx 414-22-2 genotypes, both treated with NPK + Jatropha. As shown in Figure 2, significant higher amount of total chlorophyll was recorded in the fresh leaves harvested from IT 81D-994 genotype $(62.06 \pm 1.63 \mu \mathrm{g} / 100 \mathrm{mg}) \mathrm{in}$ control treatment excepted for the same genotype treated with NPK + Jatropha $(59.90 \pm 5.41 \mu \mathrm{g} / 100 \mathrm{mg})$. 


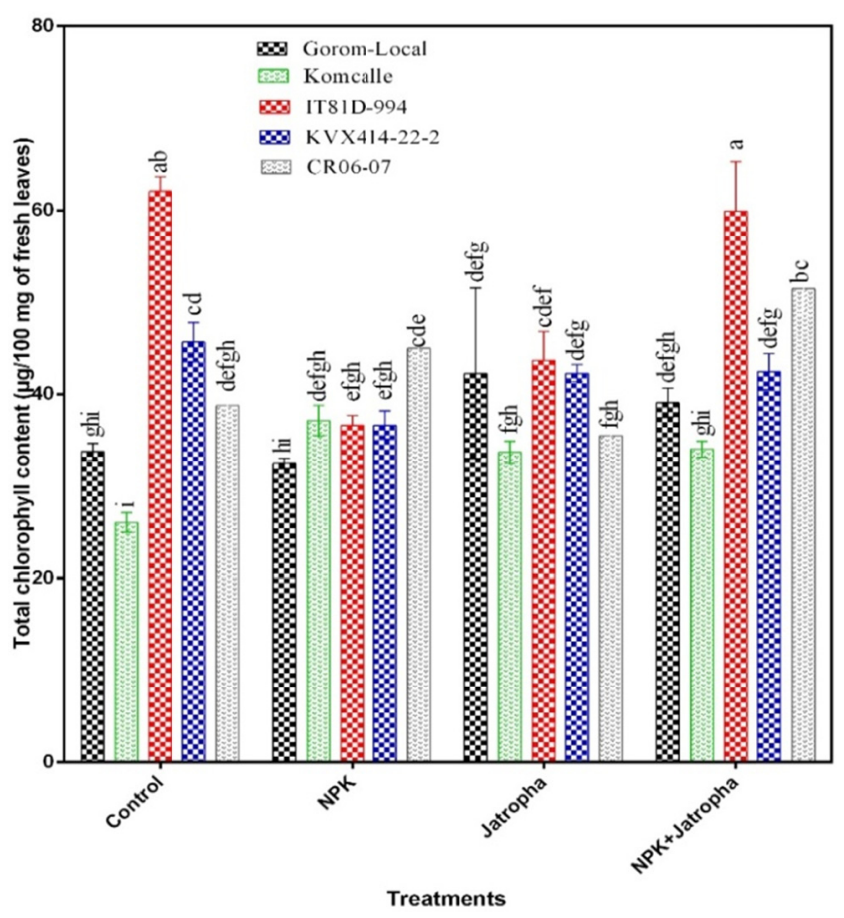

Figure 2. The interaction effect between the genotype and treatment on Total Chlorophyll content

Note. Means followed by the same letter do not differ statistically between the different treatments $(\mathrm{p}<0.05)$.

The genotype IT 81D-994 showed the significant highest lycopene contents respectively in control, Jatropha + NKP and Jatropha treatments of $15.84 \pm 0.1,13.49 \pm 0.96$ and $9.55 \pm 0.98 \mu \mathrm{g} / \mathrm{g}$ of fresh leaves (Figure 3). As also shown in Figure 3, higher value in $\beta$-carotene content was exhibited in the leaves of CR06-07 genotype harvested from NPK + Jatropha treatment $(160.49 \pm 0.83 \mu \mathrm{g} / \mathrm{g})$ followed by the same genotype treated with NPK $(158.52 \pm 2.1 \mu \mathrm{g} / \mathrm{g})$ and Jatropha treatment $(154.47 \pm 0.57 \mu \mathrm{g} / \mathrm{g})$.

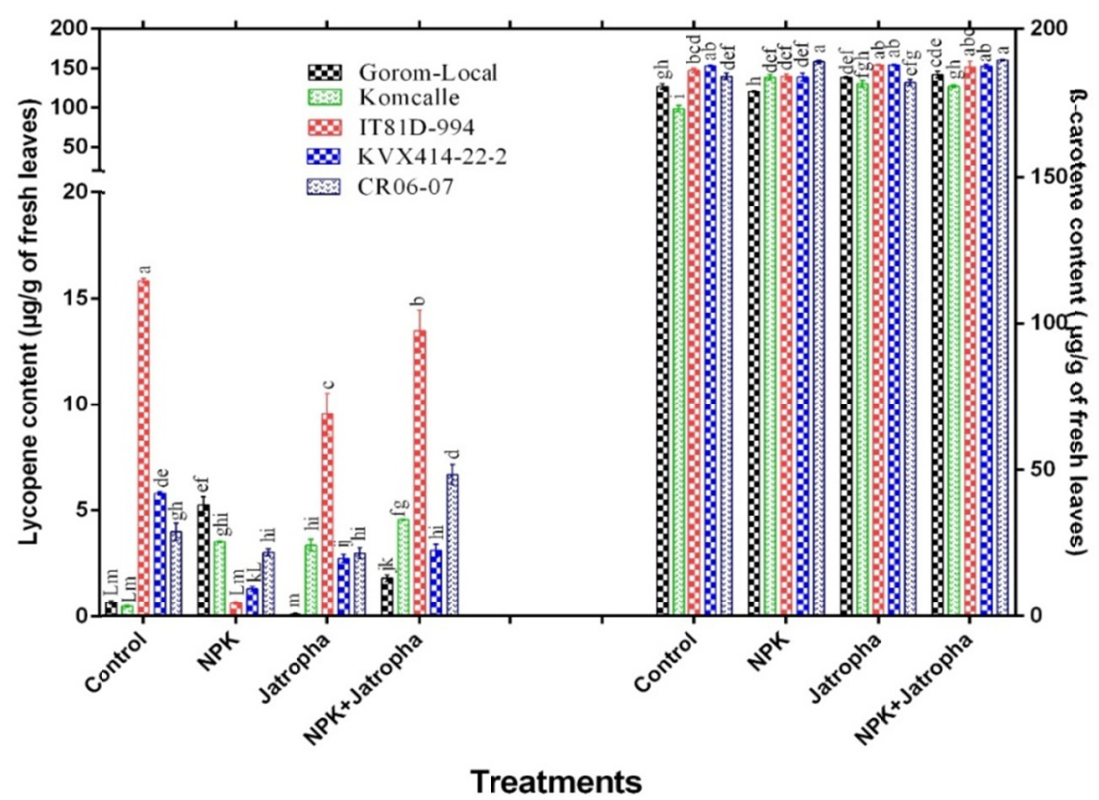

Figure 3. The interaction effect between the genotype and treatment on Carotenoids content of cowpea Note. Means followed by the same letter do not differ statistically between the different treatments $(\mathrm{p}<0.05)$. 
The protein and soluble sugars contents are represented in Figure 4.

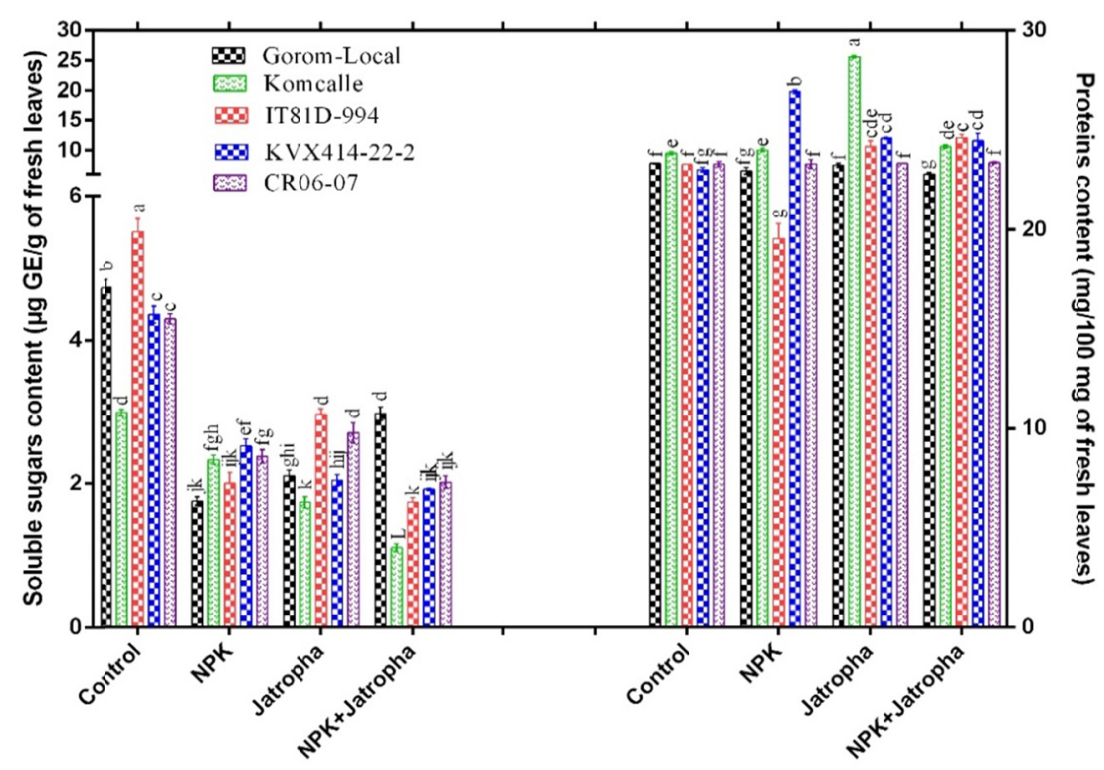

Treatments

Figure 4. The interaction effect between the genotype and treatment on soluble sugars and Protein contents of cowpea

Note. Means followed by the same letter do not differ statistically between the different treatments $(\mathrm{p}<0.05)$.

The composition of the fresh leaves in protein varies from $25.63 \pm 0.2$ to $5.41 \pm 0.21 \mathrm{mg} / 100 \mathrm{mg}$ respectively for the Komcallé genotype in Jatropha treatment and IT 81D-994 genotype in NPK treatment. Komcallé genotype treated with Jatropha contain the significant high content of protein among the genotypes of the different treatment. IT 81D-994 genotype in control treatment showed the high significant content of soluble sugars $(5.51 \pm 0.18 \mathrm{mg} \mathrm{GE} / \mathrm{g}$ of fresh leaves) and the genotype Komcallé in NPK + Jatropha treatment $(1.11 \pm 0.06 \mathrm{mg}$ $\mathrm{GE} / \mathrm{g}$ ), the low content of soluble sugar.

The total phenolics and total flavonoids of untreated and treated cowpea genotypes are represented in Figure 5. 


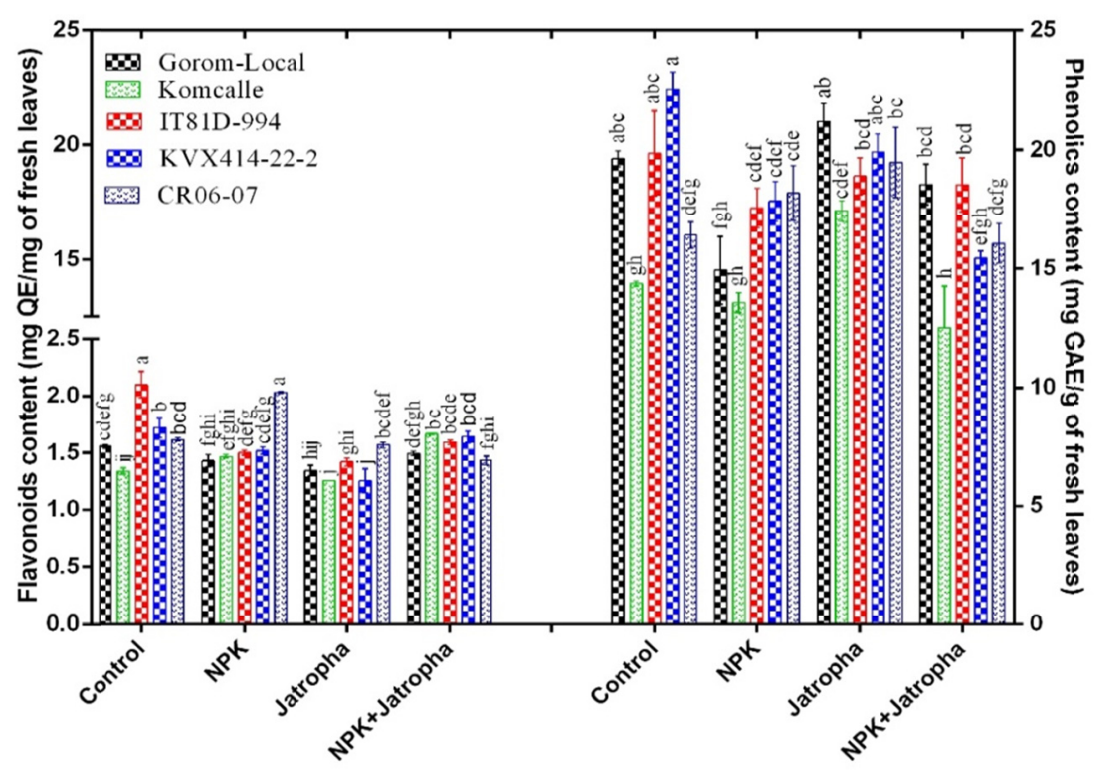

Treatments

Figure 5. The interaction effect between the genotype and treatment on Polyphenols compounds content of cowpea

Note. Means followed by the same letter do not differ statistically between the different treatments $(\mathrm{p}<0.05)$.

The results of total phenolics and total flavonoids were displayed respectively by the genotypes KVX 414-22-2

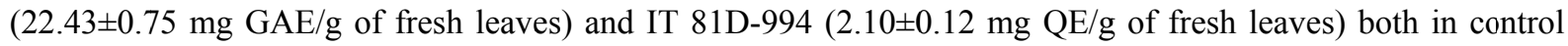
treatment. The total phenolic content of KVX 414-22-2 genotype in control treatment are not significant different with those of the same genotype and Gorom local genotype both in Jatropha treatment. Also, the total flavonoids content of IT 81D-994 genotype in control treatment is not significant different with that of CR06-07 treated with NPK.

The Ferric reduction ability and DPPH free radical scavenging potential of cowpea leaves from the different treatment were shown in Figure 6. The CR06-07 exhibited the high significant ability to reduce iron (III) in NPK, $\mathrm{NPK}+$ Jatropha and Jatropha treatments respectively of $6.96 \pm 0.14,5.55 \pm 0.24$ and $5.01 \pm 0.39 \mu \mathrm{g} / 100 \mathrm{mg}$ of fresh leaves. The KVx 414-22-2 genotype treated with Jatropha showed the significant high DPPH scavenging potential of $14.52 \pm 0.36 \mu \mathrm{g} / 100 \mathrm{mg}$ of fresh leaves excepted for Komcallé genotype treated with NPK. The lowest DPPH free radical scavenging activity was exhibited by IT 81 D-994 in control treatment $(11.90 \pm 0.00$ $\mu \mathrm{g} / 100 \mathrm{mg}$ ). 


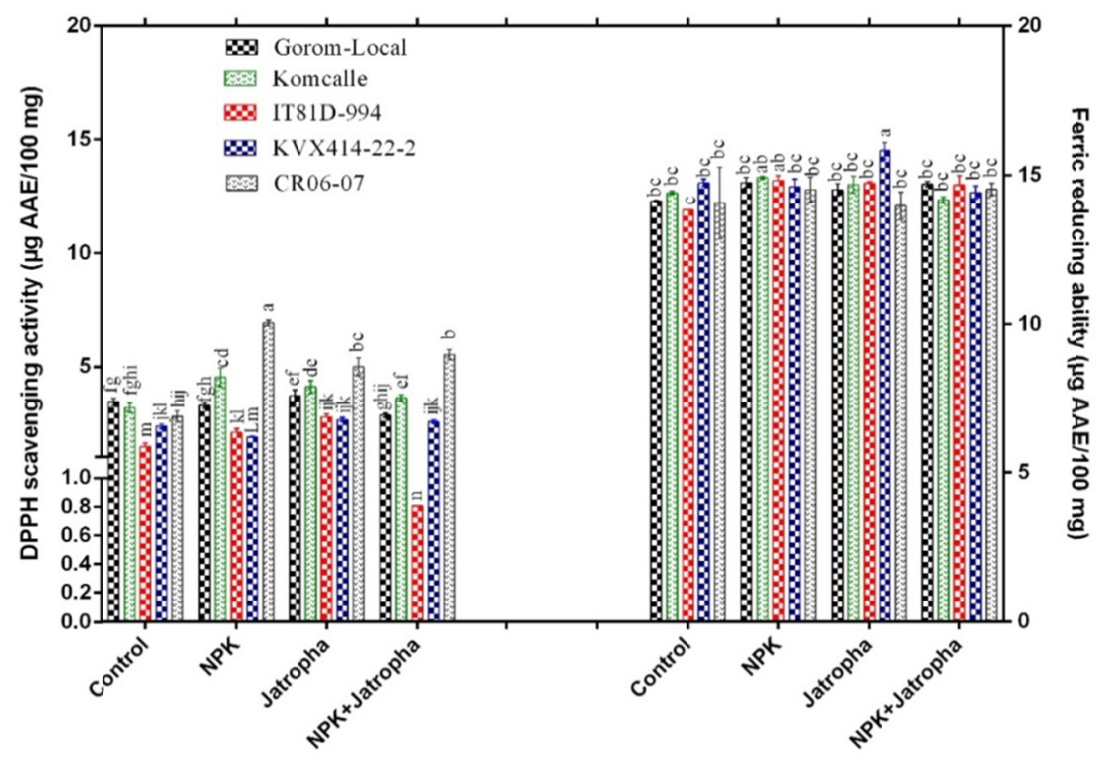

Treatments

Figure 6. The interaction effect between the genotype and treatment on Antioxidant Activities of cowpea Note. Means followed by the same letter do not differ statistically between the different treatments $(\mathrm{p}<0.05)$.

Cowpea fresh leaves trypsin inhibition activities and salicylic acid content of all the genotypes from the different treatments are shown in Figure 7.

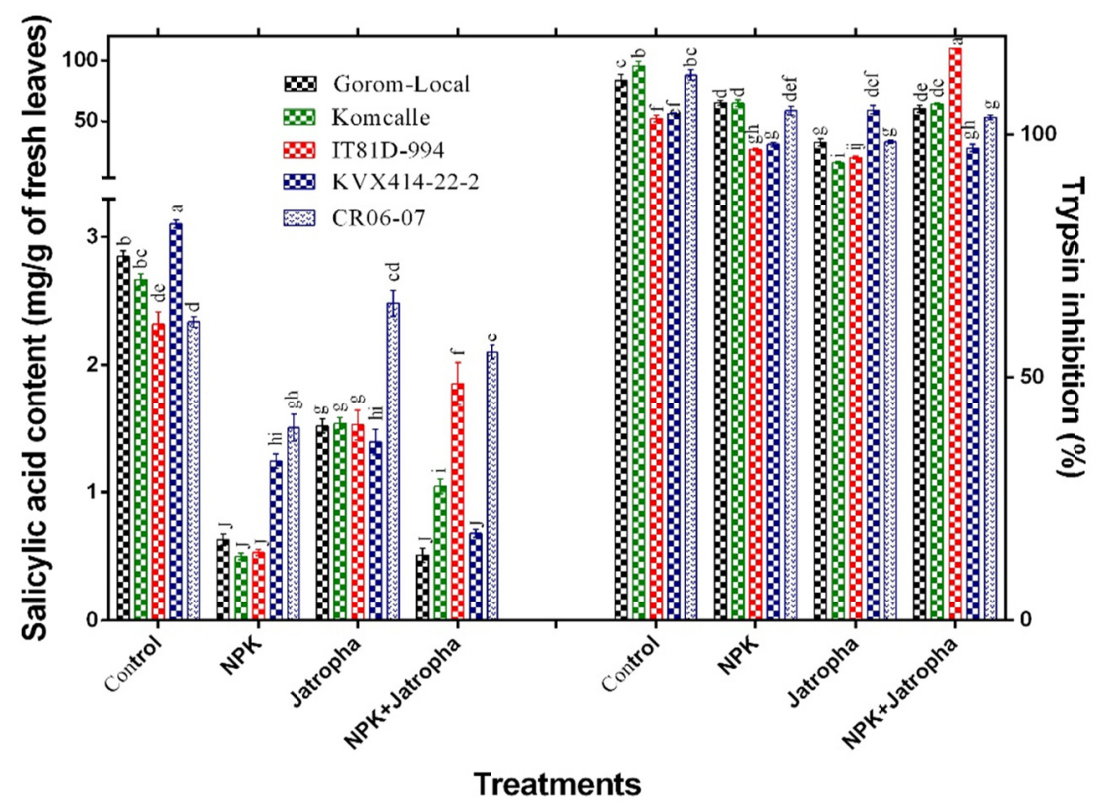

Figure 7. The interaction effect between the genotype and treatment on Salicylic acid content and Trypsin inhibition potential of cowpea

Note. Means followed by the same letter do not differ statistically between the different treatments $(\mathrm{p}<0.05)$.

The genotype of cowpea IT 81D-994 in NPK + Jatropha treatment showed the significant $(\mathrm{p}<0.05)$ high trypsin inhibition potential $(100 \pm 0.00 \%)$, followed by the genotype Komcallé in control treatment $(95.61 \pm 3.70 \%)$ and CR06-07 genotype $(88.07 \pm 4.40 \%)$ at the concentration of $100 \mathrm{mg} / \mathrm{mL}$ of fresh leaves. 
The salicylic acid content was significant depicted by the KVx 414-22-2 genotype in control treatment (3.1 \pm 0.03 $\mathrm{mg} / \mathrm{g}$ of fresh leaves) followed by the Gorom local genotype in control treatment $(2.85 \pm 0.05 \mathrm{mg} / \mathrm{g}$ of fresh leaves) and the low content was exhibited by Komcallé genotype treated with NPK $(0.50 \pm 0.02 \mathrm{mg} / \mathrm{g}$ of fresh leaves $)$.

There is a significantly interaction between genotype and treatment with $\mathrm{p}<0.001$ for the different measured parameters.

\subsection{Cowpea Growth Parameters and Leaves Quality Trait Responses Towards the Different Genotypes}

Growth parameters, biochemical components and antioxidant activities of plants are generally affected by varietal characteristics. The measured parameters of growth and leaves quality showed different responses towards the different genotypes of cowpea used (Table 2).

Table 2. Effect of different genotypes on growth, biochemical components and antioxidant activities

\begin{tabular}{|c|c|c|c|c|c|c|c|c|c|c|c|c|c|}
\hline Genotype & TC & Lycopene & B-Carotene & TP & $\mathbf{T F}$ & Protein & S. sugar & SA & FRAP & DPPH & TIA & Height & $\begin{array}{l}\text { Number of } \\
\text { branches }\end{array}$ \\
\hline IT81D-994 & $50.57^{\mathrm{a}}$ & $9.88^{\mathrm{a}}$ & $148.28^{\mathrm{a}}$ & $18.45^{\mathrm{a}}$ & $1.66^{\mathrm{a}}$ & $9.00^{c}$ & $3.05^{\mathrm{a}}$ & $1.56^{\mathrm{b}}$ & $1.78^{\mathrm{e}}$ & $12.80^{\mathrm{ab}}$ & $52.48^{b}$ & $23.83^{b}$ & $4.00^{\mathrm{a}}$ \\
\hline CR06-07 & $42.69^{b}$ & $4.18^{b}$ & $147.80^{\mathrm{a}}$ & $17.23^{b}$ & $1.67^{\mathrm{a}}$ & $7.85^{\mathrm{d}}$ & $2.85^{b}$ & $2.11^{\mathrm{a}}$ & $5.07^{\mathrm{a}}$ & $12.47^{\mathrm{b}}$ & $58.38^{\mathrm{a}}$ & $48.25^{\mathrm{a}}$ & $3.417^{\mathrm{a}}$ \\
\hline KVX414-22-2 & $41.76^{b}$ & $3.25^{\mathrm{c}}$ & $149.76^{\mathrm{a}}$ & $18.69^{\mathrm{a}}$ & $1.54^{b}$ & $12.60^{b}$ & $2.71^{c}$ & $1.61^{b}$ & $2.36^{\mathrm{d}}$ & $13.30^{\mathrm{a}}$ & $43.87^{\mathrm{c}}$ & $22.62^{b}$ & $3.75^{\mathrm{a}}$ \\
\hline Gorom Local & $36.87^{\mathrm{c}}$ & $1.963^{\mathrm{d}}$ & $132.23^{b}$ & $18.32^{a b}$ & $1.47^{c}$ & $7.03^{e}$ & $2.89^{b}$ & $1.38^{\mathrm{c}}$ & $3.32^{\mathrm{c}}$ & $12.81^{\mathrm{ab}}$ & $60.46^{\mathrm{a}}$ & $25.29^{b}$ & $4.00^{\mathrm{a}}$ \\
\hline Komcalle & $32.71^{\mathrm{d}}$ & $2.99^{\mathrm{c}}$ & $124.00^{c}$ & $14.12^{\mathrm{c}}$ & $1.44^{\mathrm{c}}$ & $14.00^{\mathrm{a}}$ & $2.04^{\mathrm{d}}$ & $1.44^{\mathrm{c}}$ & $3.86^{b}$ & $12.84^{\mathrm{ab}}$ & $60.07^{\mathrm{a}}$ & $22.54^{b}$ & $3.50^{\mathrm{a}}$ \\
\hline $\operatorname{Pr}>F$ & 0.000 & 0.000 & 0.000 & 0.000 & 0.000 & 0.000 & 0.000 & 0.000 & 0.000 & 0.000 & 0.000 & 0.000 & 0.000 \\
\hline Significative & yes & yes & yes & yes & yes & yes & yes & yes & yes & yes & yes & yes & yes \\
\hline
\end{tabular}

Note. Means in a same column followed by different letter (s) are significantly different at $\mathrm{P}<0.05$.

TC: Total Chlorophyll was expressed in $\mu \mathrm{g} / 100 \mathrm{mg}$ of fresh leaves extracts ( $\mu \mathrm{g} / 100 \mathrm{mg}$ ); $\beta$-Carotene and lycopene were expressed in $\mu \mathrm{g} / \mathrm{g}$ of fresh leaves; TP: Total Phenolics was expressed in $\mathrm{mg}$ of gallic acid equivalent per gram of fresh leaves; TF: Total Flavonoids was expressed in mg of quercetin equivalent (QE) per gram of fresh leaves; SA: Salicylic Acid was expressed in mg/g of fresh leaves; S. sugars: Soluble sugars were as expressed in mg glucose equivalent/gram; TIA: Trypsin inhibition Activity was expressed in percentage of inhibition; FRAP was expressed in $\mu \mathrm{g}$ Quercetin Equivalent per $100 \mathrm{mg}$ of fresh leaves; DPPH was expressed in $\mu \mathrm{g}$ Ascorbic acid Equivalent per $100 \mathrm{mg}$ of fresh leaves; Height was expressed in $\mathrm{cm}$.

The genotype CR06-07 possess the highest mean of height $(48.25 \mathrm{~cm})$ significantly different with those of the four others genotypes used. There is not significant difference between the genotypes in number of branches. The genotype IT 81D-994 possess the significant highest mean $(\mathrm{P}<0.0001)$ values of total chlorophyll $(50.57$ $\mu \mathrm{g} / 100 \mathrm{mg}$ of fresh leaves), lycopene $(9.879 \mu \mathrm{g} / \mathrm{g}$ of fresh leaves) and soluble sugars $(3.055 \mathrm{mg} / \mathrm{g}$ GE of fresh leaves). The highest $\beta$-carotene and total phenolics contents and free DPPH radical scavenging potential were recorded by KVx 414-22-2 genotype with an overall mean respectively of $149.76 \mu \mathrm{g} / \mathrm{g}, 18.687 \mathrm{mg} \mathrm{GAE} / \mathrm{g}$ and $13.304 \mu \mathrm{g} / 100 \mathrm{mg}$ of fresh leaves.

Total flavonoids and salicylic acid contents and ferric reduction ability of fresh leaves were obtained by the CR06-07 genotype with the means respectively of $1.67 \mathrm{mg} \mathrm{QE} / \mathrm{g} ; 2.1 \mathrm{mg} / \mathrm{g}$ and $5.07 \mu \mathrm{g} / 100 \mathrm{mg}$ of fresh leaves. The genotype Gorom local exhibited the significant high mean inhibition of trypsin (60.46\%) excepted for Komcallé genotype $(60.075 \%)$. The protein content was significantly exhibited by the Komcallé genotype with a mean of $13.998 \mathrm{mg} / 100 \mathrm{mg}$.

\subsection{Cowpea Growth Parameters and Leaves Quality Trait Responses Towards the Different Treatments}

Growth parameters, biochemical components and antioxidant activities are also affected by environmental conditions and fertilizer treatments. The two-way ANOVA analysis showed that almost all the growth and biochemical parameters were significantly different among treated and non-treated genotypes with organic and NPK fertilizers (Table 3). 
Table 3. Effect of different treatments on growth, biochemical components and antioxidant activities

\begin{tabular}{|c|c|c|c|c|c|c|c|c|c|c|c|c|c|}
\hline Treatment & TC & Lycopene & B-Carotene & TP & TF & Protein & $\begin{array}{l}\text { Soluble } \\
\text { sugar }\end{array}$ & SA & FRAP & DPPH & TIA & Height (cm) & $\begin{array}{l}\text { Number of } \\
\text { branches }\end{array}$ \\
\hline Control & $41.236^{b}$ & $5.359^{b}$ & $133.403^{c}$ & $18.30^{\mathrm{a}}$ & $1.67^{\mathrm{a}}$ & $7.94^{\mathrm{c}}$ & $4.38^{\mathrm{a}}$ & $2.65^{\mathrm{a}}$ & $2.64^{c}$ & $12.43^{\mathrm{b}}$ & $75.23^{\mathrm{a}}$ & $15.87^{\mathrm{c}}$ & $2.20^{\mathrm{c}}$ \\
\hline NPK & $37.550^{c}$ & $2.755^{\mathrm{d}}$ & $139.388^{b}$ & $16.072^{b}$ & $1.60^{b}$ & $9.95^{b}$ & $2.20^{\mathrm{c}}$ & $0.88^{d}$ & $3.74^{\mathrm{a}}$ & $13.07^{\mathrm{a}}$ & $49.40^{\mathrm{c}}$ & $30.13^{b}$ & $4.20^{\mathrm{ab}}$ \\
\hline Jatropha & $39.479^{b c}$ & $3.757^{\mathrm{c}}$ & $142.000^{b}$ & $19.16^{\mathrm{a}}$ & $1.37^{\mathrm{c}}$ & $12.77^{\mathrm{a}}$ & $2.31^{b}$ & $1.69^{b}$ & $3.65^{\mathrm{a}}$ & $13.10^{\mathrm{a}}$ & $32.33^{d}$ & $30.07^{b}$ & $3.73^{b}$ \\
\hline NPK + Jatropha & $45.410^{\mathrm{a}}$ & $5.942^{\mathrm{a}}$ & $146.864^{a}$ & $15.92^{b}$ & $1.57^{\mathrm{b}}$ & $9.73^{b}$ & $1.96^{\mathrm{d}}$ & $1.24^{\mathrm{c}}$ & $3.07^{\mathrm{b}}$ & $12.78^{a b}$ & $63.26^{\mathrm{b}}$ & $37.97^{\mathrm{a}}$ & $4.80^{\mathrm{a}}$ \\
\hline $\operatorname{Pr}>F$ & 0.000 & 0.000 & 0.000 & 0.000 & 0.000 & 0.000 & 0.000 & 0.000 & 0.000 & 0.000 & 0.000 & 0.000 & 0.000 \\
\hline Significative & Yes & Yes & Yes & Yes & Yes & Yes & Yes & Yes & Yes & Yes & Yes & Yes & Yes \\
\hline
\end{tabular}

Note. Means in a same column followed by different letter (s) are significantly different at $\mathrm{P}<0.05$.

TC: Total Chlorophyll was expressed in $\mu \mathrm{g} / 100 \mathrm{mg}$ of fresh leaves extracts $(\mu \mathrm{g} / 100 \mathrm{mg}) ; \beta$-Carotene and lycopene were expressed in $\mu \mathrm{g} / \mathrm{g}$ of fresh leaves; TP: Total Phenolics was expressed in $\mathrm{mg}$ of gallic acid equivalent per gram of fresh leaves; TF: Total Flavonoids was expressed in mg of quercetin equivalents (QE) per gram of fresh leaves; SA: Salicylic Acid was expressed in $\mathrm{mg} / \mathrm{g}$ of fresh leaves; Soluble sugar was expressed in mg glucose equivalent/gram; TIA: Trypsin inhibition Activity was expressed in percentage of inhibition; FRAP was expressed in $\mu \mathrm{g}$ Quercetin Equivalent per $100 \mathrm{mg}$ of fresh leaves; DPPH was expressed in $\mu \mathrm{g}$ Ascorbic acid Equivalent per $100 \mathrm{mg}$ of fresh leaves; Height was expressed in $\mathrm{cm}$.

The mixture of NPK and Jatropha cake improve significantly $(\mathrm{P}<0.005)$ the growth (height) of cowpea genotype $(37.967 \mathrm{~cm})$ followed by the NPK treatment solely $(30.13 \mathrm{~cm})$ and Jatropha treatment solely $(30.0670$ $\mathrm{cm}$ ) as compared to control group. The height of plants treated solely with NPK are not significantly different with those treated only with Jatropha cake. The plants treated with the mixture of NPK and Jatropha also possess the significant high number of branches (4.8) when compared to the plants of control (2.2) and Jatropha (3.73). The number of plant branches in NPK (4.2) group were not significantly different with that in Jatropha group (3.73).

The association of NPK + Jatropha used as fertilizer increased the photosynthetic pigments such as total chlorophyll with the mean of $45.55 \mu \mathrm{g} / 100 \mathrm{mg}$ of fresh leaves, lycopene $(5.94 \mu \mathrm{g} / \mathrm{g})$ and $\beta$-carotene $(146.86 \mu \mathrm{g} / \mathrm{g}$ of fresh leaves) contents.

The application of Jatropha cake as organic fertilizer enhances significantly the protein content comparatively to the others treatments with a mean of $12.77 \mathrm{mg} / 100 \mathrm{mg}$ of fresh leaves. The total phenolics content was strong in Jatropha cake treatment but not significantly different with its content in control treatment. The total flavonoids content was high in control group (1.672 $\mathrm{mg}$ QE/g of fresh leaves) with any treatment follow by NPK treated group. The leaves antioxidant activities (Ferric reduction ability and free DPPH scavenging potential) were almost the same from Jatropha and NPK treatments. The application of organic or NPK fertilizers improve the antioxidant activities when compared to control group.

Cowpea genotypes untreated (control treatment) with organic and/or NPK fertilizers showed marked increase in soluble sugars $(4.37 \mathrm{mg} \mathrm{GE} / \mathrm{g}$ of fresh leaves), salicylic acid $(2.654 \mathrm{mg} / \mathrm{g})$ and trypsin inhibition activity (75.227\%). This indicates that the cowpea genotype can be grown even at no or low $\mathrm{N}$ fertilizer level using organic fertilizers.

\subsection{Correlations Between Biochemical Components vs Growth Parameters}

The Table 4 shows the correlations between the biochemical components evaluated and growth parameters.

Table 4. Correlation between biochemical component and growth parameters

\begin{tabular}{llllllllllll}
\hline Variables & \multirow{2}{*}{ T C } & Lycopene & B-Carotene & TP & TF & Protein & $\begin{array}{l}\text { Soluble } \\
\text { Sugar }\end{array}$ & SA & FRAP & DPPH & TIA \\
\hline Height (cm) & 0.332 & -0.030 & 0.971 & -0.555 & -0.441 & 0.502 & -0.958 & -0.839 & 0.520 & 0.623 & -0.435 \\
Number of Branches & 0.244 & -0.122 & 0.917 & -0.664 & -0.339 & 0.427 & -0.963 & -0.914 & 0.564 & 0.644 & -0.403 \\
\hline
\end{tabular}

Note. TC: Total Chlorophyll. TP: Total Phenolics. TF: Total Flavonoids. SA: Salicylic Acid. TI: Trypsin Inhibition Activity.

Positive and significant correlations were found between plant height and $\beta$-carotene content $(r=0.971)$, total protein content $(r=0.502)$, DPPH radical scavenging activity $(r=0.623)$ and Ferric reducing ability $(r=0.52)$. 
Positive significant correlations were also found between the branches number of cowpea genotypes and $\beta$-carotene content $(r=0.917)$, total protein content $(r=0.427)$, DPPH radical scavenging activity $(r=0.644)$ and Ferric reducing ability $(\mathrm{r}=0.564)$. Lows positive and significant relationships were found between the total chlorophyll content and height $(\mathrm{r}=0.332)$ and total chlorophyll content and number of plant branches $(\mathrm{r}=$ $0.244)$.

The height of plant was negatively correlated with the content of total phenolics $(r=-0.555)$, total flavonoids $(r$ $=-0.441)$, soluble sugars $(r=-0.958)$, salicylic acid $(r=-0.839)$ and trypsin inhibition activity $(r=-0.435)$. The number of branches was also negatively correlated with the content of total phenolics $(r=-0.664)$, total flavonoids $(r=-0.339)$, soluble sugars $(r=-0.963)$, salicylic acid $(r=-0.913)$ and trypsin inhibition activity $(r=$ -0.403). The lycopene content was not significantly correlated with the height and the number of plants branches.

\subsection{Comparative Analysis of the Organic and NPK Fertilizers on the Growth, Biochemical Components and} Antioxidant Activities of Cowpea Genotypes

The principal component analysis was performed on the basis of the different fertilizers effect on growth parameters, biochemical components and antioxidant activities of the cowpea varieties. The Figure 8 presents the repartition of the growth parameters and antioxidant components in the biplot axis.

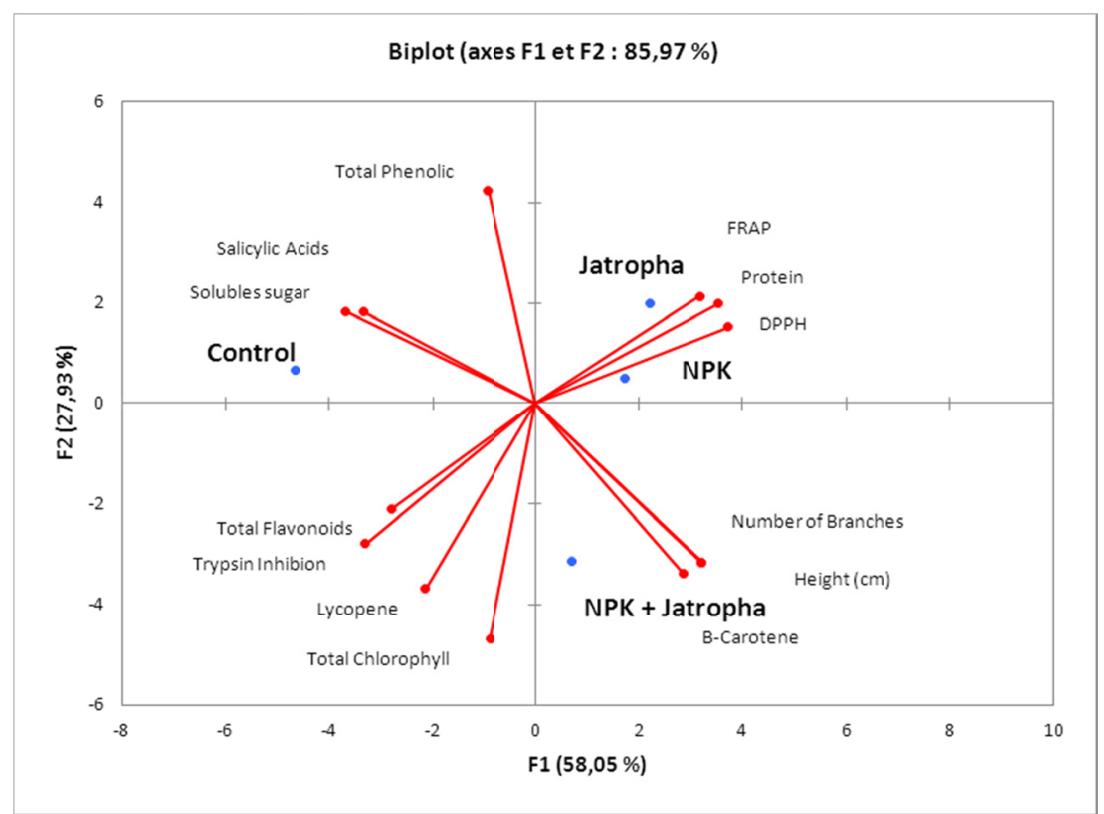

Figure 8. Principal component analysis of the effect of different treatments on growth, biochemical components and antioxidant activities

The first two principal components explained $88.97 \%$ of the total variance. The first principal component (F1) and the second principal component (F2) account respectively for 58.05 and $27.93 \%$ of the total variation. The first principal component (F1) separated the control treatment from the groups treated with organic, NPK and the mixture of organic and NPK fertilizers. The second principal component (F2) separated the control group and group treated with the mixture of NPK + Jatropha, and in other hand the groups treated solely with NPK, Jatropha and the mixture of NPK + Jatropha. The analyze of the correlations between the evaluated variables and factors showed strong contribution of the NPK + Jatropha treatment to lycopene, $\beta$-carotene and total chlorophyll contents, height and number of branches. The NPK or Jatropha treatment are highly link to the variables FRAP, DPPH and protein. The control treatment contributes strongly to salicylic, soluble sugars, phenolics and flavonoids contents and trypsin inhibition activity. After the construction of dendrogram of the different treatments, the treatments were grouped into three main classes, I, II and III (Figure 9). Class I comprised Jatropha + NPK treatment, class II has two treatments and comprised NPK treatment solely and Jatropha treatment solely, class III has one treatment and comprised control treatment. 


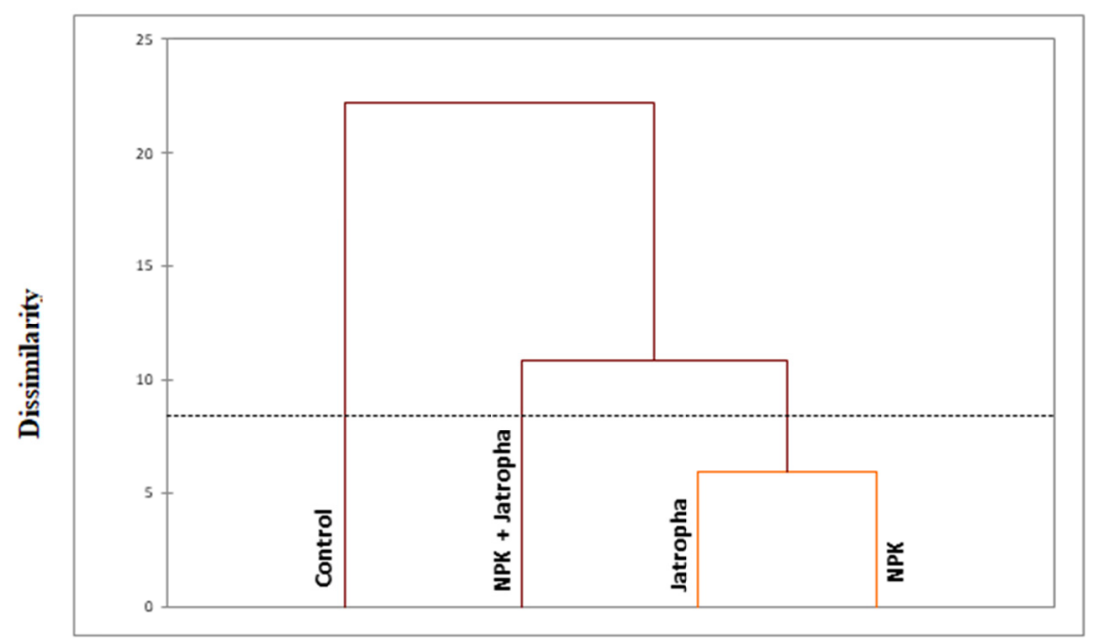

Figure 9. Dendrogram of the effect of treatment constructed for the auto-scaled growth, biochemical components and antioxidant activities data of cowpea genotypes

\section{Discussion}

This study indicated that utilization of NPK, Jatropha, mixture of NPK and Jatropha fertilizers increase the growth parameters and the content of some quality traits of cowpea leaves comparatively to control treatment. The contents of various biochemical components and antioxidant activities responded positively to Jatropha or NPK + Jatropha fertilization. The jatropha cake, an organic fertilizer could supply nutrients, improve physical, chemical and biological aspects of soil fertility (Agegnehu, Nelson, \& Bird, 2016). Combined application of organic and inorganic fertilizers increases plant growth, yield, quality and soil fertility in plants (Patil, 2010). The application of the mixture of Jatropha cake and NPK fertilizer enhanced nutrient uptake (N, P and K) in cowpea genotype as indicated by increasing the growth parameters (height and number of branches), the photosynthetic pigments (total chlorophyll) and carotenoids content (lycopene and $\beta$-carotene) of leaves. Strong correlations are observed between the growth parameters, the photosynthetic pigments and the carotenoids content. These strong relationships indicate that the mixture of Jatropha cake and NPK increased the growth of cowpea by enhancing the photosynthesis processes. The productivity of any crops depends on the photosynthesis process, which in turn depends on the chlorophyll content in plants leaves (Mondal et al., 2015).

Protein content increased at all the treatments compared to the control group. It showed maximum content at Jatropha treatment as compared to control and others NPK and NPK + Jatropha treatments. Protein synthesis turnover in growing plants is a basic component of metabolic regulation which provides a way for varying the enzymatic complement during the response to environmental conditions (Patil, 2010). The high content of protein in Jatropha treated group as compared to the others treated and control groups could be due to the increase of nitrogen supply which has paramount effect in the synthesis of protein (Fadlalla, Abukhlaif, \& Mohamed, 2016).

The ferric reducing ability of leaves and DPPH radical scavenging activity were link to class II composed by two treatment: Jatropha solely and NPK solely treatment. The PCA study and the dendrogram showed that the antioxidant activities were increased in the NPK treatment or Jatropha treatment. A higher value of DPPH free radical scavenging potential of Moringa leaves treated with NPK and compost treatment at the rate of $50+50 \%$ was reported (Sarwar et al., 2019). Some authors also reported that 2,2-diphenyl-1 picrylhydrazyl radical scavenging and iron reducing properties were increased by the application of organic manure and conclude that the combined use of organic manure with urea fertilizer led to enhanced antioxidant activities (Olarewaju et al., 2018). The strong correlations observed between antioxidant activities (FRAP and DPPH) and growth parameters (height and number of branches) showed a direct contribution of antioxidant compounds to the growth of cowpea. The Jatropha and the mixture of jatropha and NPK fertilization have positive effects on the synthesis of compounds with strong antioxidant properties as compared to control treatment.

The principal components analysis (PCA) and the dendrogram link total phenolics, total flavonoids, soluble sugars, salicylic acid contents and trypsin inhibition activity to class III and comprised control treatment. Total phenolics and total flavonoids contents are important parameters to estimate polyphenol accumulation by plants in response to fertilizer treatments. These compounds were influenced by cowpea genotype and type of 
fertilization. The contents of these compounds are high in control treatment as compared to the different others treated groups and also negatively correlated with the growth parameters. The results are in contrast with the work of Ozdemir et al. (2018) who observed a significantly increased of total phenolics and total flavonoids content in berry pulp and seed part of the grapes from plants grown under organic and organo-mineral fertilizer applications.

It is also reported that $M$. olefeira treated with NPK and compost $(50+50 \%)$ in combination, depicted higher phenolics and flavonoids contents as compared to the control (Sarwar et al., 2019). According to Olarewaju et al. (2018), the increased biomass in treated group can leads to reduced synthesis of secondary metabolites (polyphenolic compounds). The phenolic compounds contents are reduced when the phenylalanine amount is low as the protein accumulation increased when the nitrogen concentration is higher (Jones \& Hartley, 1999). The presumed role of phenolics is the protection of cell constituents against oxidative damage by acting as reducing agents, single oxygen quenchers, and free radical hydrogen donors (Baradi et al., 2018).

The content of salicylic acid is significantly higher in control treatment as compared to the different others treated groups and also negatively strongly correlated with the growth parameters. The cowpea genotypes under control treatment are stresses highly as compared to the plants of the others treatments groups because of the poorly of the soil in nutrients. The increased content of SA is to help control plant to resist to stress causes by the lack of nutrients. Salicylic acid (SA), a phenolic compound has been recognized as a regulatory signal mediating plant response to abiotic stresses and also plays a crucial role in the regulation of physiological and biochemical processes during the entire lifespan of the plant (Rivas-San Vicente \& Plasencia, 2011). Significant difference in total soluble sugars content in cowpea leaves among the different treatments could be attributed toward the variable rate of photosynthesis (Mondal et al., 2015). The percentage of trypsin inhibition is significantly higher in control treatment as compared to the different others treated groups and also slowly negatively correlated with the growth parameters. In contrast Zhang, Collins, and Andrade (1998) showed that the trypsin inhibitor activity of nine sweetpotato lines increased in fertilized soil as compared to unfertilized soil in four environments.

Significant differences between the treatments and variety $\mathrm{T} \times \mathrm{V}$ interaction $(\mathrm{P}<0.0001)$ for growth parameters, biochemical components and antioxidant activities of cowpea were recorded. The significant differences in cowpea productivity observed in the five genotypes indicated the strong genotypic impact on the treatments.

\section{Conclusion}

The results of the present study showed that the growth and quality of cowpea leaves were affected by type of fertilization and genotype. The interaction effect of treatment $x$ genotype was significant $(p<0.0001)$. Application of Jatropha cake, NPK or the mixture of NPK and Jatropha cake to cowpea genotypes showed excellent results in increase of growth, biochemical content and antioxidant activities as compared to control treatment. Jatropha cake is effective and low-cost fertilizer that can be promoted solely or in mixture with NPK as eco-friendly organic fertilizer. Present study concludes that combined application of NPK and organic fertilizers increase the growth and biochemical responses of cowpea genotypes toward synthesis and accumulation of pigments content such as total chlorophyll and carotenoids. Understanding the influence of the different fertilizer treatments on the production and quality traits of cowpea genotypes will lead to the development of appropriate fertilizer management. This study serves as guide to farmers in their crop management to produce more and better quality of cowpea leaves.

\section{Acknowledgements}

This research has been supported by TWAS under individual Fellowship Grant given to the first author.

\section{References}

Agegnehu, G., Nelson, P. N., \& Bird, M. I. (2016). Crop yield, plant nutrient uptake and soil physicochemical properties under organic soil amendments and nitrogen fertilization on Nitisols. Soil \& Tillage Research, 160, 1-13. https://doi.org/10.1016/j.still.2016.02.003

Baradi, M. A., Magno, M. F., Solero, J., Ancheta, R., Corpuz, G., \& Romero, M. (2018). Influence of fertilizer treatments on the milling potentials and total phenolic content of aromatic rice. American Journal of Agriculture and Forestry, 6(6), 263-275.

Bradford, M. (1982). A rapid and sensitive method for the quantitation of microgram quantities of protein utilizing the principle of protein-dye binding. Analytical Biochemistry, 72, 248-254. https://doi.org/10.1016/ 0003-2697(76)90527-3 
Dubois, M., Gilles, K. A., Hamilton, J. K., Rebers, P. A., \& Smith, F. (1956). Colorimetric method for determination of sugars and related substances. Analytical Chemistry, 8(3), 350-356. https://doi.org/ 10.1021/ac60111a017

Fadlalla, H. A., Abukhlaif, H. A. A., \& Mohamed, S. S. (2016). Effects of chemical and bio-fertilizers on yield, yield components and grain quality of maize (Zea mays L.). African Journal of Agricultural Research, 11(45), 4654-4660. https://doi.org/10.5897/AJAR2016.11619

Jones, C. G., \& Hartley, S. E. (1999). A protein competition model of phenolic allocation. Wiley-Blackwell, 86(1), 27-44. https://doi.org/10.2307/3546567

Ju, I., Wj, B., Md, S., Ia, O., \& Oj, E. (2018). A review biofertilizer-A key player in enhancing soil fertility and crop. Microbiol Biotechnol Rep, 2(1), 22-28.

Klomklao, S., Benjakul, S., Kishimura, H., Osako, K., \& Tanaka, M. (2009). A heat-stable trypsin inhibitor in adzuki bean (Vigna angularis): Effect of extraction media, purification and biochemical characteristics. International Journal of Food Science \& Technology, 45(1), 163-169. https://doi.org/10.1111/j.1365-2621. 2009.02117.x

Maria, D., Rodica, S., \& Gabriella, D. M. (2017). The effect of organic fertilization on fruit production and quality of tomatoes grown in the solar. Annals of the university of craiova-Agriculture, Montanology, Cadastre Series, XLVII, 112-118.

Mondal, T., Datta, J. K., \& Mondal, N. K. (2015). Chemical fertilizer in conjunction with biofertilizer and vermicompost induced changes in morpho-physiological and bio-chemical traits of mustard crop. Journal of the Saudi Society of Agricultural Sciences.

Nagata, M., \& Yamashita, I. (1992). Simple method for simultaneous determination of chlorophyll and carotenoids in tomato fruit. J. Japan. Soc. Foods Sci. Technol., 39(10), 925-928. https://doi.org/10.3136/ nskkk1962.39.925

Olarewaju, O. A., Alashi, A. M., Taiwo, K. A., Oyedele, D., Adebooye, O. C., \& Aluko, R. E. (2018). Influence of nitrogen fertilizer micro-dosing on phenolic content, antioxidant, and anticholinesterase properties of aqueous extracts of three tropical leafy vegetables. Journal of Food Biochemistry, 42(4), e12566. https://doi.org/10.1111/jfbc. 12566

Ozdemir, G., Kitir, N., Turan, M., \& Ozlu, E. (2018). Impacts of organic and organo-mineral fertilizers on total phenolic, flavonoid, anthocyanin and antiradical activity of okuzgozu (Vitis vinifera L.) grapes. Acta Scientiarum Polonorum Hortorum Cultus, 17(3), 91-100. https://doi.org/10.24326/asphc.2018.3.9

Patil, N. M. (2010). Biofertilizer effect on growth, protein and carbohydrate content in Stevia rebaudiana VAR BERTONI. Recent Research in Science and Technology, 2(10), 42-44.

Primandari, S. R. P., Islam, A. K. M. A., Yaakob, Z., \& Chakrabarty, S. (2018). Jatropha Curcas L. Biomass Waste and Its Utilization. Advances in Biofuels and Bioenergy. https://doi.org/10.5772/intechopen.72803

Rivas-San Vicente, M., \& Plasencia, J. (2011). Salicylic acid beyond defence: Its role in plant growth and development. Journal of Experimental Botany, 62(10), 3321-3338. https://doi.org/10.1093/jxb/err031

Sama, H., Sombié, P. A. E. D., Hilou, A., Bonzi, S., \& Somda, I. (2018). Biochemical Resistance mechanism study of Jatropha curcas (Euphorbiaceae) against Lasiodiplodia theobramae, a leaf blight and necrosis agent. Journal of Agriculture and Crops, 4(12), 176-185. https://doi.org/10.32861/jac.412.176.185

Sarwar, M., Patra, J. K., Ali, A., Maqbool, M., \& Arshad, M. I. (2019). Effect of compost and NPK fertilizer on improving biochemical and antioxidant properties of Moringa oleifera. South African Journal of Botany. https://doi.org/10.1016/j.sajb.2019.01.009

Sombié, P. A. E. D., Compaoré, M., Coulibaly, A., Ouédraogo, J., Tignégré, J.-B., \& Kiendrébéogo, M. (2018). Antioxidant and phytochemical studies of 31 cowpeas (Vigna unguiculata (L. Walp.)) genotypes from Burkina Faso. Foods, 7(9), 143. https://doi.org/10.3390/foods7090143

Sombié, P. A. E. D., Hilou, A., Mounier, C., Coulibaly, A. Y., Kiendrebeogo, M., Millogo, F. J., \& Nacoulma, O. G. (2011). Antioxidant and anti-inflammatory activities from galls of Guiera senegalensis J.F. GMEL (Combretaceae). Research Journal of Medicinal Plant, 5(4), 448-461. https://doi.org/10.3923/rjmp.2011. 448.461 
Verma, S., Singh, A., Pradhan, S. S., Singh, R. K., \& Singh, J. P. (2017). Bio-efficacy of organic formulations on crop production-A review. Int. J. Curr. Microbiol. App. Sci., 6(5), 648-665. https://doi.org/10.20546/ ijcmas.2017.605.075

Wintermans, J. F. G. M., \& DeMots, A. (1965). Spectrophotometric characteristics of chlorophylls a and b and their pheophytins in ethanol. Biochim. Biophysica. Acta, 109, 448-453. https://doi.org/10.1016/0926-6585 (65)90170-6

Yang, T., Zhu, L.-S., Meng, Y., Lv, R., Zhou, Z., Zhu, L., ... Xi, D.-H. (2018). Alpha-momorcharin enhances Tobacco mosaic virus resistance in tobacco NN by manipulating jasmonic acid-salicylic acid crosstalk. Journal of Plant Physiology, 223, 116-126. https://doi.org/10.1016/j.jplph.2017.04.011

Zhang, D., Collins, W. W., \& Andrade, M. (1998). Genotype and fertilization effects on trypsin inhibitor activity in Sweetpotato. Hort Science, 33(2), 225-228. https://doi.org/10.21273/HORTSCI.33.2.225

\section{Copyrights}

Copyright for this article is retained by the author(s), with first publication rights granted to the journal.

This is an open-access article distributed under the terms and conditions of the Creative Commons Attribution license (http://creativecommons.org/licenses/by/4.0/). 